\title{
ANALYSIS OF DIFFERENTIALLY EXPRESSED GENES IN RESPONSE TO BACTERIAL STIMULATION IN HEMOCYTES OF THE CARPET-SHELL CLAM Ruditapes decussatus: IDENTIFICATION OF NEW ANTIMICROBIAL PEPTIDES
}

\author{
Gesta I C., Costa M.M., Figue ras A., Novoa B. \\ Instituto de Investigaciones Marinas. Consejo Superior de Investigaciones Científicas \\ (CSIC). Eduardo Cabello 6, Vigo. Spain
}

Revised Version

Corresponding address:

Antonio Figueras

Institu to de Investigaciones Marinas

Consejo Superior de Investigaciones Científicas (CSIC)

Eduardo Cabello 6, 36208 Vigo

Spain

e-mail: antoniofigueras@iim.csic.es 


\begin{abstract}
Suppression subtractive hybridization was used to identify differentially expressed genes in hemocytes from carpet shell clam Ruditapes decussatus stimulated with a mixture of dead bacterial strains. Putative function could be assigned to 100 of the 253 sequenced cDNAs. Based on sequence homologies, $3.16 \%$ of the total identified genes were possibly related to immune functions. Clam myticin isoforms 1,2 and 3, and clam mytilin, with similarity with myticins and mytilins previously reported on Mytilus galloprovincialis were identified and characterized for the first time in clams. The analysis of their expression levels by quantitative PCR showed that they were induced by bacterial challenge. The results obtained in this work could be the first step leading to the understanding of molecular mechanisms by which these economically important marine bivalves respond to pathogens.
\end{abstract}

Key words: antimicrobial peptides, clam, immune-response, Myticin, Mytilin, Ruditapes decussatus, SSH. 


\section{Introduction}

In recent years bivalve culture has grown in importance worldwide but diseases, favoured by high densities, cause significant economical loses. Diseases affecting these organisms have traditionally been studied using histological techniques, which have proved to be very useful to detect pathogens, but also to determine the lesions and the interaction of the pathogens with the host immune defense mechanisms (Figueras \& Novoa, 2004). Today, most of the knowledge on clam (Ruditapes decussatus) innate immunity is based on functional assays (Ordás et al., 2000; Tafalla et al., 2003). However, almost nothing is known on the molecular basis of clam immune responses. Interest in bivalve genomics has emerged during the last decade, due to the importance of these organisms in aquaculture and fisheries and to their role in marine environmental science (Saavedra \& Bachère, 2006). However, bivalve genomics is at its beginning, and the available data refers only to a very small number of genes (Venier, et al., 2006). Thus, few studies have been conducted on the expressed immune genes in response to infections in bivalve molluscs (Tanguy et al., 2004; Gueguen et al., 2003; Kang et al., 2006).

Techniques such as mRNA differential display or Suppression Subtractive Hybridization libraries may facilitate the identification of genes involved on bivalve immune response (Tan guy et al., 2004). The selection of genes induced by infection that could be related with resistance may be used as molecular markers of interest to assist in the selection of strains for aquaculture (Figueras \& Novoa, 2004).

Bivalves lack a specific immune system and therefore do not possess immune memory, but they have developed an innate immune system involving cell-mediated and humoral components used to recognize and eliminate pathogens. The hemocytes are the cells primarily involved in inflammation, wound repair, encapsulation and phagocytosis, and it is in the hemolymph where the most potent components of the bivalve immune response are localized (Pipe, 1990). They recognize unique and characteristic pathogen-associated molecular patterns (PAMPs) using host pattern recognition receptors (PRRs) (Medzhitov, \& Janeway 2000; Kang et al., 2006). In addition, the cell free hemolymph contains specific soluble substances such as antimicrobial peptides secreted by the hemocytes, among others. These constitute important components of the immune system for all phyla from plants to animals including bacteria, being exceptionally diverse in sequence, structure and function (Cellura et al., 2007). In bivalve molluses, antimicrobial peptides have only been 
identified in oysters Crassostrea gigas and C. virginica (Gonzalez et al., 2007; Seo et al., 2004) and mussels Mytilus galloprovincialis and M. edulis (Charlet et al., 1996; Hubert, et al., 1996; Mitta et al., 1999a; Mitta et al., 1999b). Taking into account the features of their primary structure and their consensus cysteine array, these peptides were classified in four groups: i) mytilins, with five isoforms (A, B, C, D and G1) (Mitta et al., 2000a; Mitta et al., 2000b), ii) myticins, with three isoforms A, B (Mita et al., 1999), and C (Pallavicini et al. in press), iii) defensins, found in both mussel and oysters, with two isoforms (MGD1 and MGD2) in M. galloprovincialis; defensin A and B in M. edulis, Cg-Def1 and Cg-Def2 in C. gigas, and AOD (American oyster defensin) in C. virginica (Charlet et al., 1996; Mitta et al., 2000a, Gonzalez et al., 2007; Seo et al., 2004); and iv) mytimicin, partially characterized from M. edulis plasma (Charlet et al., 1996). However, until now no antimicrobial peptides have been described in carpetshell clams, and only one expressed sequence tag (EST) obtained from a cDNA library from other clam species, $R$. philippinarum infected with Perkinsus olseni, had similarity with mussel defensin MGD-1 (Kang et al., 2006).

The main goal of this paper is the identification and characterization of genes involved in the immune response of the bivalve mollusc Ruditapes decussatus, one of the most economically important clam species cultured in Galicia (NW Spain). The use of the SSH technique will allow us to identify differentially expressed gen es in response to a particular stimulus.

\section{Material and methods}

\subsection{Maintenance of clams}

Carpet-shell clams, R. decussatus, were obtained from a commercial shellfish farm. Animals were maintained in open circuit filtered seawater tanks at $15^{\circ} \mathrm{C}$ with aeration and they were fed daily with Isochrysys galbana $\left(12 \times 10^{8}\right.$ cells/animal), Tetraselmis suecica $\left(10^{7}\right.$ cells/animal) and Skeletonema costatum $\left(3 \times 10^{8}\right.$ cells/animal). Prior to the experiments, bivalves were acclimatised for 1 week.

\subsection{Immune stimulation, hemolymph withdrawal and RNA isolation}

A total of 50 clams were notched in the shell in the area adjacent to the adductor muscles and injected into the adductor muscle with $100 \mu \mathrm{l}$ (containing $10^{7}$ cells $/ \mathrm{ml}$ ) of a mixture of dead bacteria (Micrococcus lysodeikticus, Vibrio splendidus and Vibrio anguillarum), kindly donated by Philippe Roch (UMR CNRS Ecolag, Université de 
Montpellier 2, France). Other group of 50 clams were injected with $100 \mu$ of filtered sea water (FSW) and used as controls. After the stimulation, clams were returned to the tanks and maintained for 48 hours at $15^{\circ} \mathrm{C}$ until sampling.

Hemolymph (0,5 -1 ml) was withdrawn from the adductor muscle of each animal with a dispo sable syringe. Hemolymph collected from fifty individual clams was pooled and centrifuged at $2500 \mathrm{xg}$ during 15 minutes at $4^{\circ} \mathrm{C}$. The pellet was resuspended in $6 \mathrm{ml}$ of Trizol (Invitrogen) and the RNA was extracted according to the manufacturer's protocol.

\subsection{Suppression-subtractive hybridization.}

The Suppression Subtractive Hybridization technique (SSH) (Diatchenko et al., 1996) was used to characterize new genes involved in the carpet-shell clam's innate immune response against the mixture of dead bacteria $48 \mathrm{~h}$ after stimulation. Briefly, cDNA was synthesized from $1 \mu \mathrm{g}$ of each hemocyte RNA sample (bacterial infected and control not infected) using the SMART PCR cDNA Synthesis Kit (Clontech). A SSH assay was then performed using the PCR-Select cDNA Subtraction Kit (Clontech) following manufacturer's instruction (Pallavicini et al., in press), and using the cDNA of infected tissues as tester, and the cDNA of non-infected tissues or control as driver. The PCR mixture of differentially expressed was cloned using the TOPO TA cloning kit (Invitrogen) and transformed in E. coli competent cells.

Selected colonies were amplified by PCR using Nested PCR primer 1 and 2R from PCR-Select cDNA Subtraction Kit (SSH technique). Agarose gel electrophoresis was performed to check and select by size the samples to be sequenced and arrayed. The PCR profile consisted of: initial denaturation for $5 \mathrm{~min}$ at $94^{\circ} \mathrm{C} ; 35$ cycles of $30 \mathrm{~s}$ denaturation at $94^{\circ} \mathrm{C}, 30 \mathrm{~s}$ annealing at $65^{\circ} \mathrm{C}$ and $1.5 \mathrm{~min}$ elongation at $72^{\circ} \mathrm{C}$; final extension for $7 \mathrm{~min}$ at $72^{\circ} \mathrm{C}$. Excess primers and nucleotides were removed by enzymatic digestion using $10 \mathrm{U}$ and $1 \mathrm{U}$ of ExoI and SAP, respectively (Amersham Biosciences) at $37^{\circ} \mathrm{C}$ for $1 \mathrm{~h}$ followed by inactivation of the enzymes at $80^{\circ} \mathrm{C}$ for 15 min. DNA sequencing was performed using a BigDye terminator Cycle Sequencing Ready Reaction Kit and an automated DNA sequencer ABI 3730.

\subsection{Sequencing analys is}

Raw chromatograms were analysed with Chromas 231 software (Technelysium). Search for similarities with known genes was performed using BLAST (http://www.ncbi.nlm.nih.gov/blast). Translation and protein analysis were carried out using the ExPaSy tools (http://us.expasy.org/tools). Multiple sequence alignments were 
generated with Clustal W (Thompson et al., 1997). Database search was performed using BlastX and the best annotated hit from the similarity search was retained. Novel ESTs were deposited in GeneBank and assigned accession numbers EL903716EL903793.

\subsection{Identification and characterization of new AMP. Isolation of full-length transcripts}

In order to get the full length ORF cDNA of selected sequences, those ESTs with high similarity with the known AMPs mytilin and myticin sequences were used to design primers for 5' cDNA. RACE reactions were performed using SMART RACE cDNA Amplification Kit from Clontech according to the manufacturer's instructions. A 5'RACE primer (MYTL-CC.1: 5'- GGAAAGGTCTATTAACACAGGTCG-3') for mytilin, and a 5' RACE (MYT-CC.2: 5'-GTGCCAATGGAGACTCAGCTCTGCGAC3') for myticin were designed by Primer 3 software (Rozen and Skaletsky, 2000). After cloning in pGem-T Vector System (Promega) and transformation in Top 10F' competent bacteria (Invitrogen), several clones were sequenced from both ends with M13 forward and reverse primers using BigDye terminator Cycle Sequencing Ready Reaction Kit and an automated DNA sequencer ABI 3730.

A retro transcription was performed to obtain cDNAs using the SuperScriptII RNAase H- Reverse Transcriptase (Invitrogen) from $5 \mu \mathrm{g}$ of the original RNA. The resulting cDNA was subjected to a PCR reaction using a primer pairs (MYTL-CC F3: 5'-GTTCAATATCTACATCTTTAAG-3' and MYTL-CC R2: 5' CTATTAACACAGGTCGAATC-3') for mytilin, and (MYT-CC F: 5'AGTACGCGGGGGGCTTCTAC-3' and MYT-CC R: 5'AGCAGAAAACGTCGAAAGCG-3') for myticin, that were designed in order to check the full length AMP sequences obtained by RACE. The cleavage site for the signal peptide was determined by analysis with SignalP (Bendtsen et al., 2004).

\subsection{Phylogenetic analysis}

In addition to the sequences obtained in this study, sequences of the complete ORF of mytilins and myticins obtained from the GenBank were also included in the analysis: myticin A (AAD47638); myticin B (AAD47639); mytilin B (AAD52661); mytilin C (AAU44785). rRNA sequences were aligned with ClustalW (Thompson et al., 1997) including in MEGA 3 (Kumar et al., 2004). A phylogenetic tree based on deduced amino acid ORF sequences was performed using the Neighbour-Joining (NJ) algorithm 
with the MEGA3 software programme. Statistical confidence on the inferred phylogenetic relationships was ass essed by bootstrap of 1000 replicates.

\subsection{Expression analys is of the identified AMP genes}

In order to confirm the differentially expression of the antimicrobial peptides identified as up-regulated in the SSH library at $48 \mathrm{~h}$ post injection, and to evaluate and quantify their relative expression, a real time SYBR Green PCR assay was carried out using the same hemocytes cDNA previously used for the SSH library. Results were obtained from three different qPCRs.

An additional experiment was carried out to determine the expression of the clam AMPs after infection with dead bacteria (the same bacterial mixture previously used) or live $V$. anguillarum. For each treatment, three pools of 4-5 clams were injected into the adductor muscle with $100 \mu \mathrm{l}$ (containing $10^{7}$ cells $/ \mathrm{ml}$ ) of dead or live bacteria. The same protocol was used for controls injecting FSW. Hemolymph and RNA samples were obtained as previously described.

Quantitative PCR assays and data analysis were performed using 7300 Real Time PCR System (Applied Biosystems). The $25 \mu 1$ PCR mixture include of $12.5 \mu 1$ of SYBR Green PCR master mix (Applied Biosystems) with $0.5 \mu$ lof primers pairs $10 \mu \mathrm{M}$ (MYT-CCQ F: 5'-ACAAACTTCATCCCGGCAAA-3'; MYT-CCQ R: 5'GGTCCAAATGTTCCATCTCATTC-3' for Myticins, and MYTL-CCQ F: 5'AAGGTGAAACTGGAATGTAAAGAGAAG-3' and MYTL-CCQ R: 5'AAGGTCTATTAACACAGGTCGAATCA-3' for mytilins), and $1 \mu 1$ of a 1:5 dilution of the cDNA. Amplification was carried out at the standard cycling conditions of $95^{\circ}$ for $10 \mathrm{~min}$, followed by 40 cycles of $95^{\circ} 15 \mathrm{~s}$ and $60^{\circ}$ for $1 \mathrm{~min}$. The comparative CT method (2- $\Delta \Delta \mathrm{CT}$ method) was used to determine the expression level of analyzed genes (Livak and Schmittgen, 2001). The expression of the candidate genes was normalized using $18 \mathrm{~S}$ fragment as a housekeeping gene by the specific primers 18S-F: 5'GGGAAGAGCGCTTTTGTTAG-3' and 18S-R: 5'- GCATAGCACGTACCATCGAC3'. Fold units were calculated dividing the normalized expression values of infected tissues by the normalized expression values of the controls. Results are given as the mean and standard deviation of three replicates and pools.

\section{Results}

3.1. ESTs sequencing and identification 
A total of 253 clones obtained from hemocyte SSH libraries were isolated, amplified by PCR and sequenced. BLASTx analysis and comparison of ESTs against GenBank databases was performed to find the sequence similarity. A total of 119 sequences grouped in 78 contigs were potential protein-coding genes. Of them, 100 sequences, grouped in 64 contigs showed a significant match to known proteins (Table 1). A total of 75 transcripts were redundant (representing 63\% sequences). An overview of the obtain ed results is displayed in Table 2. Only matches with e-values smaller than $10 \mathrm{e}^{-3}$ were retained as significant. The genes identified were clustered and graphically represented into eight functional categories (Fig. 1): (1) Some of the identified transcripts ( 6 clone clusters, including 8 ESTs, representing $3.16 \%$ ) were probably involved in immune defense; (2) a total of 7 clone clusters (including 10 ESTs, $3.95 \%$ ) showed similarity with genes involved in cell signaling and adhesion; (3) a total of 14 clone clusters, (including 26 ESTs, $10.28 \%$ ) were potentially related to cytoskeleton structure; (4) 17 clusters (32 ESTs, $12.65 \%$ ) showed similarity with genes involved in cell cycle; (5) a total of 14 clone clusters (including 18 ESTs, 7.11\%) showed similarity with genes involved in cell metabolism and respiratory chain;(6) and 6 clone clusters (6 ESTs, $2.37 \%)$ were ribosomal proteins. The remaining 19 obtained transcripts $(7.5 \%$ of the total sequences) were not classified, and considered to have unknown functions (Table. 1). A total of 134 analyzed transcripts showed no significant result or no hit.

Among the ESTs with direct or indirect immune functions: two clusters showed similarity with proteins involved in stress (HSP 70 and ferritin), one cluster had similarity with proteins of apoptosis inhibition (IAP), one with the polypeptide "Naegleriapore" and two with antimicrobial peptides.

\subsection{Analys is of antimicrobial peptides}

The sequence clustering and BLASTx similarity searching of the SSH obtained ESTs showed two independent EST clusters which can be putatively identified as precursors of the antimicrobial peptides myticin and mytilin respectively. After amplification of the complete ORF by 5' RACE, cloning and sequencing, a total of 3 sequences coding for different amino acid sequences showed evident similarity with the described myticins. Moreover, one sequence presented similarity with the described mytilins. The full length ORF nucleotide and aminoacid sequences of the three new isolated myticin and mytilin forms from R. decussatus are presented in Fig. 2 and 3 respectively. 
The new myticin forms that we have named "clam myticin" presented a $300 \mathrm{bp}$ ORF encoding 100 amino acid residues. The 5' untranslated region (UTR) was only partially sequenced. However, the 3' UTR was sequenced un til the Poly A, and contains 163 base pairs. The analysis of the aminoacid sequence of the three forms showed a shared common structure. The consensus cystein array characteristic of Myticin family was conserved. A signal peptide of 20 amino acids was localized in the N-terminal region. The cleavage site for the signal peptidase was located after the A preceding the Q, at position 20 for the form 1, and after the S preceding the V, at position 22 for the forms 2 and 3 (Fig. 2). A 40-residue sequence corresponding to the mature peptide, as well as a highly conserved C-terminal extension of also 40 residues were observed. Aminoacidic diversity was found in 13 positions between the three different forms $(9$ between form 1 and form 2; 10 between form 1 and form 3; and 7 between form 2 and form 3), and in 55 positions compared with the previously described myticins A and B (Fig. 4A). The new mytilin form that we have named "clam mytilin" presented a partial sequence of $508 \mathrm{bp}$ long, with a 297 bp complete ORF that code for 99 amino acid residues. The partial 5' untranslated region (UTR) contained 39 nucleotides, and the complete 3' UTR region contains 173 nucleotides until the Poly A. The consensus cystein array characteristic of Mytilin family was detected. A signal peptide of 24 amino acids was localized in the $\mathrm{N}$-terminal region (Fig. 3). This mytilin peptide differs only in 2 amino acidic residues from the mytilin C previously described in mussels (Fig. 4B). A 34-residue sequence correspond ing to the mature peptide was observed.

The phylogenetic tree constructed with the amino acid sequences of the herein described clam AMPs, together with all the described groups of Myticins and Mytilins identified in mussels, showed two main clusters. Neighbor-Joining phylogenetic analysis supported clam myticin forms as a separated sister taxon to the mussel myticins, with a bootstrap of $100 \%$, and clam mytilin as a sister taxon of mussel mytilins. The high bootstrap (98\%) strongly favors the position of clam mytilin close to mytilin C. (Fig. 5).

\subsection{Expression patterns of AMP transcripts}

Quantitative PCR analysis were performed to determine the relative expression pattern of the two different antimicrobial peptides identified as up-regulated in the hemocyte SSH library at $48 \mathrm{~h}$ post-infection, and also to validate this technique. A significant induction of the expression levels of both AMPs was detected in bacterial 
stimulated clams (1109.6 \pm 636.9 for clam myticin, and 886.1 \pm 459.4 for clam mytilin), in contrast with non-infected controls $(0.139 \pm 0.238$; and $0.562 \pm 0.605$ respectively). Both AMPs were only slightly expressed in controls. However, bacterial infections induced an increase of 7982.7 and 1576.7 fold for clam myticin and clam mytilin respectively (Fig. 6A).

In addition, Q-PCRs performed on hemocytes from clams injected with dead bacteria or $V$. anguillarum showed a similar expression pattern after 24 and $48 \mathrm{~h}$ postinjection, although the increment with respect to controls was lower if we compare it with that obtained using the cDNA of the SSH library. Both myticin and mytilin expression levels were increased after bacterial challenge (Fig. 6B). The highest expression levels were observed $48 \mathrm{~h}$ post in fection in both challenges.

\section{Dis cussion}

The understanding of the molecular mechanisms by which clams, bivalves, and invertebrates in general, are able to mount an immune response to pathogens remains largely unknown. To our knowledge there are few studies on immune-related genes identification and their expression carried out in bivalve molluscs (Gueguen et al., 2003; Kang et al., 2006 and Venier et al. 2006). The study of differential gene expression by $\mathrm{SSH}$ is a promising approach to identify and characterize genes involved in the host response against pathogens not only in bivalves, but in different aquatic invertebrate and vertebrate groups (Ursic-Bedoya et al., 2007; Lorgeril et al., 2005; Bayne et al., 2001 Tanguy et al., 2004; He et al. 2004; Pan et al., 2005, Jenny et al., 2006, Dios et al, 2007). Recently, sea urchin immune genes have been widely investigated (Hibino et al., 2006; Rast et at., 2006; Lapraz et al., 2006; Nair et al., 2005; Courtney Smith et al., 2001). Despite some specific findings (Gueguen et al., 2003; Tanguy et al., 2004; Kang et al., 2006), mostly on oysters, very little is known concerning the molecular mechanisms involved in the recognition, activation and effector molecules of bivalves immune response to pathogens. The only work related to the molecular basis of clam immune response infected by pathogens was by Kang et al. (2006), that prepared a Manila clam cDNA library and also studied the expression of two lectins in Perkinsus olseni or by Vibrio tapetis infected clams.

The subtracted cDNA library enriched with gene transcripts differentially expressed in bacterial stimulated clams, showed that several transcripts obtained from hemocytes, the main cellular effectors in invertebrate immune defense, could be 
classified as stress and immune response related. Other ESTs had several developmental and metabolic cell functions. Most of the sequences characterized in the present work are new ESTs, and some of them have unknown functions in clams up. Further studies are needed to characterize those gen es, which will be the goal of future researches.

Among the various components that putatively could have an immune role associated, two stress proteins, HSP70 and ferritin, were identified as being upregulated in the bacterial infected clams. Heat-shock proteins are molecular chaperones that protect the cell and maintain homeostasis under stressful conditions. The HSP70 is a well known stress related protein already described in several bivalve species, including the oyster (Crassostrea gigas), mediterranean mussel (Mytilus galloprovinciallis), the manila clam (Ruditappes philipinarum) (Tanguy et al., 2004; Cellura et al., 2007 and Kang et al., 2006), and also in the pacific abalone (Haliotis discus hannai) (Cheng et al., 2007), a marine gasteropod with growing economic importance. This protein is inducible by a variety of stressful conditions, not only heat shock and contaminants, but also by pathogens and pathophysiological conditions related to inflammation (Cheng et al., 2007). The ferritin was the other stress protein found as being up-regulated in our experimentally in fected clams. This protein had been classified as stress protein due to their similarity with proteins involved in detoxification processes triggered by stress (Gueguen et al., 2003). Beck et al. (2002), indicated that ferritin can be considered an acute phase protein that regulate iron and free cations as a defense mechanism against the alteration of the arrangement of plasma proteins and serum concentrations of the cations copper, zinc and iron during inflammation process.

Proteins of apoptosis inhibition (IAP), which could be related to the inhibition of the apoptosis induced by the stress and the infection, and Naegleriapore, a pore forming polypeptide of the pathogenic protozoan Naegleria fowleri (Herbst et al., 2002), were also identified as being up-regulated in our experiments.

Additionally, two AMPs which presented similarity with already known mussel antimicrobial peptides were also identified. In this work we report for the first time the full length of three different clam myticin isoforms and a clam mytilin. These peptides showed similarity with known mussel mytilin and myticin genes, sharing their polypeptide structure and consensus cystein array characteristic of each group. However, aminoacidic diversity of the clam myticin forms identified was found in 13 positions among the three different forms ( 9 between form 1 and form 2; 10 between form 1 and form 3; and 7 between form 2 and form 3), and in 55 positions compared 
with the previously described mussel myticins A and B. Aminoacidic diversity was found with the newly described myticin C (Pallavicini et al., in press). Clam mytilin differs highly from mussel mytilins A, B, G1 and D, but only in 2 amino acidic residues from Mytilin C.

It is accepted that myticins are essentially active against gram-positive bacteria, and less active against gram-negative bacteria and fungi. However, mytilins display a wider spectrum of activity according to isoforms (Mitta et al., 2000c). Mussel hemocytes are a site of storage and production of AMPs. They are sensible to different microbial substances and after stimulation, hemocytes degranulate and release into the extracellular fluid a series of substances involved in immune defense, including "specific" antimicrobial peptides (Mitta et al., 1999a). The variation in aminoacidic residues of the different AMP types or forms can give as a result the variation in the protein produced, which could generate a specific differentiation for recognition of different types of pathogens.

Only one AMP (an EST with similarity to mussel defensin MGD-1, Kang et al. 2006) has previously been identified in Perkinsus olseni infected Manila clams. Defensins are involved in the anti-infectious process, but no striking discrepancies have been observed in haemocyte expression between naïve and bacteria challenged oysters and mussels at different infection times (González et al., 2007). The expression of this AMP was not induced after bacterial challenge (Mitta et al., 1999b; Gueguen et al., 2006). The constitutive expression of these AMPs, and their unaltered or even decreased transcription level after bacterial challenge, together with the limited sequencing effort, could explain their absence from our SSH library.

Clam myticin and mytilin showed increased expression levels by Q-PCR, 24 and $48 \mathrm{~h}$ post injection in clams injected with the mixture of dead bacteria and on those injected with live $V$. anguillarum. Q-PCR results obtained at $48 \mathrm{~h}$ post injection confirmed those obtained in SSH library cDNA. However clam myticin and mytilin expression levels were significantly higher when Q-PCR was performed using SSH cDNA. This difference could be due to several reasons such as differences in clam stocks or to seasonal variations in the immune response as it has been shown in mussels (Santarem et al. 1994)

The present work constitutes one of the first studies on Ruditapes decussatus gene identification and their modulation by bacterial infection using the suppression subtractive hybridization technique. Although we have focused on the two AMPs 
characterized by the first time on clam hemocytes, most of the analyzed genes were not previously identified in molluscs. The relatively high diversity of AMP types and their isoforms and their possible specificity in the immune response constitutes them as an interesting research topic. Moreover, further study of the described genes is needed since the identification of molecular markers related to bacterial resistance could be very useful for selection purposes in bivalve aquaculture.

\section{Acknowledgements}

This work has been partially funded by the European Commission through the Marie Curie European Reintegration Project ERG-CT-2005-518007 and the Integrated Research project FOOD-CT-2005-007103, by the Xunta de Galicia (project PGIDIT06PXIC402124A4) and by the Spanish MEC (AGL2003-02454). We thank Philippe Roch for providing the mix of dead bacteria. C.G. wishes to acknowledge additional funding from the Spanish Ministerio de Educación y Ciencia through the "Ramón y Cajal" Contract, and M.M.C. through the FPI Spanish research grant.

\section{References}

Bayne, C.J., Gerwick, L., fujiki, K., Nakao, M., Yano, T., 2001. immune-relevant (including acute phase) genes identified in the livers of rainbow trout, Onchorhynchus mykiss, by means of suppression subtractive hybridization. Dev. Comp. Immunol. 25, 205-217.

Beck, G., Ellis, T.W., Habicht, G.S., Schluter, S.F., Marchalonis, J.J., 2002. Evolution of the acute phase response: iron release by echinoderm (Asterias forbesi) coelomocytes, and cloning of an echimoderm ferritin molecule. Dev. Comp. Immunol. 26, 11-26.

Bendtsen, J.D., Nielsen, H., Heijne, G., Brunak, S., 2004. Improved prediction of signal peptides: SignalP 3.0. J. Mol. Biol. 340, 783-795.

Cellura, C., Toubiana, M., Parrinello, N., Roch, P., 2007. Specific expression of antimicrobial peptide and HSP70 genes in response to heat-shock and several bacterial challenges in mussels. Fish Shellfish Immunol. 22(4), 340-50

Charlet, M., Chernish, S., Philippe, H., Hetru, C., Hoffmann, J.A., Bulet, P., 1996. Innate immunity isolation of several cystein-rich antimicrobial peptides from the blood of a mollusc, Mytilus edulis. J. Biol. Chem. 271 (369), 21808-21813. 
Cheng, p., Liu, X., Zhang, G., He, J., 2007. Cloning and expression analysis of a HSP70 gene from Pacific abalone (Haliotis discus hannai). Fish Shellfish Immunol. 22, 7787.Courtney Smith, L., Clow, L.A., Terwilliger, D.P., 2001. The ancestral complement system in sea urchin. Immunol. Rev. 180, 16-34.

Diatchenko, L., Lau, Y.F., Campbell, A.P., Chenchik, A., Moqadam, F., Huang, B., Lukyanov, S., Lukyanov, K., Gurskaya, N., Sverdlov, E.D., Siebert, P.D., 1996. Suppression subtractive hybridization: a method for generating differentially regulated or tissue-specific cDNA probes and libraries. Proc. Natl. Acad. Sci. USA., 93(12), 6025-6030.

Dios S, Dios S, Poisa-Beiro L, Figueras A, Novoa B., 2007. Suppression subtraction hybridization ( $\mathrm{SSH})$ and macroarray techniques reveal differential gene expression profiles in brain of sea bream infected with nodavirus. Mol. Immunol. 44(9), 2195 2204.

Figueras, A., Novoa, B., 2004. What has been going on in Europe in bivalve pathology?. Bull. Eur. Ass. Fish Pathol. 24(1), 16-21.

Gonzalez, M., Gueguen, Y., Desserre, G., Lorgeril, J., Romestand, B., Bachère, E., (2007). Molecular characterization of two isoforms of defensin from hemocytes of the oyster Crassostrea gigas. Dev. Comp. Immunol. 31, 332-339.

Gueguen, Y., Cadoret, J.P., Flament, D., Barreau-Roumiguière, C., Girardot, A.L., Garnier, J., Hoareau, A., Bachère, E., Escoubas, A., 2003. Immune gene discovery by expressed sequence tags generated from hemocytes of the bacteria-challenged oyster, Crassostrea gigas. Gene 303,139-145.

Gueguen, Y., Amaury, H., Aumelas, A., Garnier, J., Fievet, J., Escoubas, J.M., Bulet, P., González, M., Lelong, C., Favrel, P. and Bachère, E. 2006. Characterization of a defensin from the oyster Crassostrea gigas. J. Biol. Chem. 281(1): 313-323.

He, N., Liu, H., Xu, X., 2004. Identification of genes involved in the response of haemocytes of Penaeus japonicus by suppression subtractive hybridization ( $\mathrm{SSH}$ ) following microbial challenge. Fish Shellfish Immunol. 17, 121-128.

Herbst, R., Ott, C., Jacobs, T., Marti, T., Marciano-Cabral, F., Leippe, M., 2002. Poreforming Polypeptides of the Pathogenic protozoan Naegleria fowleri. J. Biol. Chem. 277 (25), 22353-22360.

Hibino, T., Loza-Coll, M., Messier, C., Majeske, A., Cohen, A.H., Terwilliger, D.P., Buckley, K.M., Brockton, V., Nair, S.V., Berney, K., Fugmann, S.D., Anderson, 
M.K., Pancer, Z., Cameron, R.A., Smith, L.C., Rast, J.P., 2006. The immune gene repertoire encoded in the purple sea urch in genome. Dev. Biol. 300, 349-365.

Hubert, F., Noël, T., Roch, P., 1996. A member of the arthropod defensin family from the edible Mediterranean mussels (Mytilus galloprovincialis). Eur. J. Biochem. 240, 302-306.

Jenny, M.J., Warr, G.W., Ringwood, A.H., Baltzegar, D.A., Chapman, R.W. regulation of metallothionein genes in the American oyster (Crassotrea virginica): ontogeny and differential expression in response to different stressors. Gene 379, 156-165.

Kang, Y.S., Kim, Y.M., Park, K.Ll., Cho, S.K., Choi, K.S., Cho, M., 2006. Analysis of EST and lectin expression in hemocytes of Manila clams (Ruditapes phylippinarum) (Bivalvia: Mollusca) infected with Perkinsus olseni. Dev. Comp. Immunol. 30 (12), 1119-31.

Kumar, S., Tamunra, K., Nei, M., 2004. Mega 3: Integrated software for molecular evolutionary genetic analysis and sequence alignment. Brief Bioinf. 5:150-163.

Lapraz, F., Röttinger, E., Duboc, V., Range, R., Duloquin, L., Walton, K., Wu, S.Y., Bradham, C., Loza, M.A., Hibino, T., Wilson, K., Poustka, A., McClay, D., Angerer, L., Gache, C., Lepage, T., 2006. RTK and TGF- $\beta$ signaling pathways genes in the sea urch in genome. Dev. Biol. 300, 132-152.

Livak, K.J., Schmittgen, T.D., 2001. Analysis of relative gene expression data using real-time quantitative PCR and the 2(-Delta Delta C(T)) method. Methods 25: 402408.

Lorgeril, J., Sau hnier, D., Janech, M., Gueguen, Y., Bachère, E., 2005. Identification of genes that are differentially expressed in hemocytes of the Pacific blue shrimp (Litopenaeus stylirostris) surviving an infection with Vibrio penaeicida. Physiol. Genomics 21, 174-183.

Medzhitov, R., Janeway, C., 2000. Innate immune recognition: mechanisms and pathways. Immunol. Rev. 173, 89-97.

Mitta, G., Hubert, F., Roch, P., 1999a. Myticin, a novel cysteine-rich antimicrobial peptide isolated from hemocytes and plasma of the mussel Mytilus galloprovincialis. Eur. J. Biochem. 265, 71-78.

Mitta, G., Vandenbulcke, F., Hubert, F., Roch, P., 1999b. Mussel defensins are synthesised and processed in granulocytes then released into the plasma after bacterial challenge. J. Cell Sci. 112, 4233-4242. 
Mitta, G., Hubert, F., Elisabeth A. Dyrynda, Boudry, P., Roch, P., 2000a. Mytilin B and MGD2, two antimicrobial peptides of marine mussels: gene structure and expression analysis. Dev. Comp. Immunol. 24, 381-393.

Mitta, G., Vandenbulches, F., Hubert, F., Salzet, M., Roch, P., 2000b. Involvement of Mytilins in Mussel antimicrobial defense. J. Biol. Chem. 275 (17), 12954-12962.

Mitta, G., Vanderbulcke, F., Roch, P., 2000c. Original involvement of antimicrobial peptides in mussel innate immunity. Minireview FEBS lett. 486, 185-190.

Nair, S.V., Del Valle, H., Gross, P.S., Terwilliger, D.P., Courtney Smith, L., 2005. Macroarray analysis of coelomocyte gene expression in response to LPS in the sea urchin. Identification of unexpected immune diversity in an invertebrate. Physiol. Genomics 22, 33-47.

Ordás, M.C., Ordás, A., Beloso, C., Figueras, A., 2000. Immune parameters in carpet shell clams naturally infected with Perkinsus atlanticus. Fish Shellfish Immunol. 10, 597-609.

Pallavicini, A., Costa, M. M., Gestal, C., Dreos, R., Figueras, A., Venier, P., Novoa, B., (2007). High sequence variability of myticin transcripts in haemocytes of immunestimulated mussels suggests ancient host-pathogen interactions. Dev. Comp. Immunol. In press.

Pan, D., He, N., Yang, Z., Liu, H., Xu, X., 2005. Differential gene expression profile in hepatopancreas of WSSV-resistant shrimp (Penaeus japonicus) by suppression subtractive hybridization. Dev. Comp. Immunol. 29, 103-112.

Pipe, R.K. 1990. Hydrolitic enzymes associated with the granular haemocytes of the marine mussel Mytilus edulis. Histochem. J. 22, 595-603.

Rast, J.P., Courtney Smith, L., Loza-Coll, M., Hibino, T., Litman, G.W., 2006. Genomic insigh ts into the immune system of the sea urchin. Science 314, 952-956.

Rozen, S., Skaletsky, H., 2000. Primer3 on the WWW for general users and for biologists programmers. Methods Mol. Biol. 132:365-386.

Saavedra, C., Bachère, E., 2006. Bivalve genomics. Aquaculture. 256 (1-4), 1-14.

Santarém, M.M., Robledo, J.A.F., Figueras, A., 1994. Seasonal changes in hemocytes and humoral defence factors in blue mussels (Mytilus galloprovincialis). Dis. Aquat. Org. 18: 217-222.

Seo, J.K., Crawford, J.M., Stone, K.L., Noga, E.J., 2004. Purification of a novel arthropod defensin from the American oyster, Crassostrea virginica. Biochem. Bioph. Res. Comm. 338, 1998-2004. 
Tafalla, C., Gómez-León, J., Nocoa, B and Figueras, A., 2003. Nitric oxide production by carpet shell clam (Ruditapes decussatus) hemocytes. Dev. Comp. Immunol. 27, 197-205.

Tanguy, A., Guo, X., Ford, S.E., 2004. Discovery of genes expressed in response to Perkinsus marinus challenge in Eastern (Crassostrea virginica) and Pacific $(C$. gigas) oysters. Gene 338, 121-131.

Thompson J.D., Gibson, T.J., Plewniak, F., Jeanmou gin, F., Higgins, D.G., 1997. The Clustal $\mathrm{X}$ windows in terface: flexible strategies for multiple sequence alignment aided by quality tools. Nuc. Acids Res. 24, 4876-4882.

Ursic-Bedoya, R., Lowenberger, C.A., 2007. Rhodnius prolixus: identification of immune-related genes up-regulated in response to pathogens and parasites using suppressive subtractive hybridization. Dev. Comp. Immunol. 31, 109-120.

Venier, P., De Pittà, C., Pallavicini, A., Marsano, F., Varotto, L., Romualdi, C; Dondero, F., Viarengo, A., Lanfranchi, G., 2006. Development of mussel mRNA profiling: Can gene expression trends reveal coastal water pollution?. Mutat. Res.Fundam. Mol. Mech. Mutagen. 602 (1-2), 121-134. 


\section{Figure Legends:}

Fig. 1. Functional classification of $R$. decussatus hemocyte ESTs. The 253 ESTs were clustered into 6 categories according with their putative biological function.

Fig 2. Complete ORF nucleotide and deduced amino acid sequences of the tree different Clam myticin forms. Signal peptides are in grey. ( $\boldsymbol{\nabla})$ Indicate the cleavage sites. $(*)$ Indicate the stop codons. A. Clam myticin form 1; B. Clam myticin form 2; C. Clam myticin form 3.

Fig 3. Complete ORF nucleotide and deduced amino acid sequence of the Clam mytilin sequence. Signal peptide is in grey. ( $\boldsymbol{\nabla})$ Indicate the cleavage site. $(*)$ Indicate the stop codon.

Fig. 4. A. Multiple alignment of clam myticin forms compared with mussel myticin A and B. B Multiple alignment of amino acidic sequences of the clam mytilin compared with related mytilins. (*) identical residues, (:) conserved substitutions and (.) semiconserved substitutions. The most similar sequences are highlighted in grey, and the amino acidic differences between these two forms are in bold. The cystein consensus array, in grey, is also shown.

Fig. 5. Neighbour-Joining (NJ) tree of the ORF aminoacid sequence data shows the phylogenetic relationships among the three forms of the Clam myticin AMP (form 1, 2 and 3), the Clam mytilin, and the complete ORF of myticins and mytilins previously reported in mussels. Bootstrap: 100 repetitions.

Fig. 6. Quantitative expression of clam myticin and clam mytilin in hemocyte samples of $R$. decussatus. A. AMPs expression in hemocyte cDNA obtained by SSH library at $48 \mathrm{~h}$ post-infection with a mixture of dead bacteria. B. AMPs expression in clams injected with a mixture of dead bacteria or $V$. anguillarum after 24 and $48 \mathrm{~h}$ postinfection. Results are mean \pm SD. Bars represent the relative expression transcript levels of infected clams referred to controls, previously normalized to $18 \mathrm{~S}$ transcript levels. 


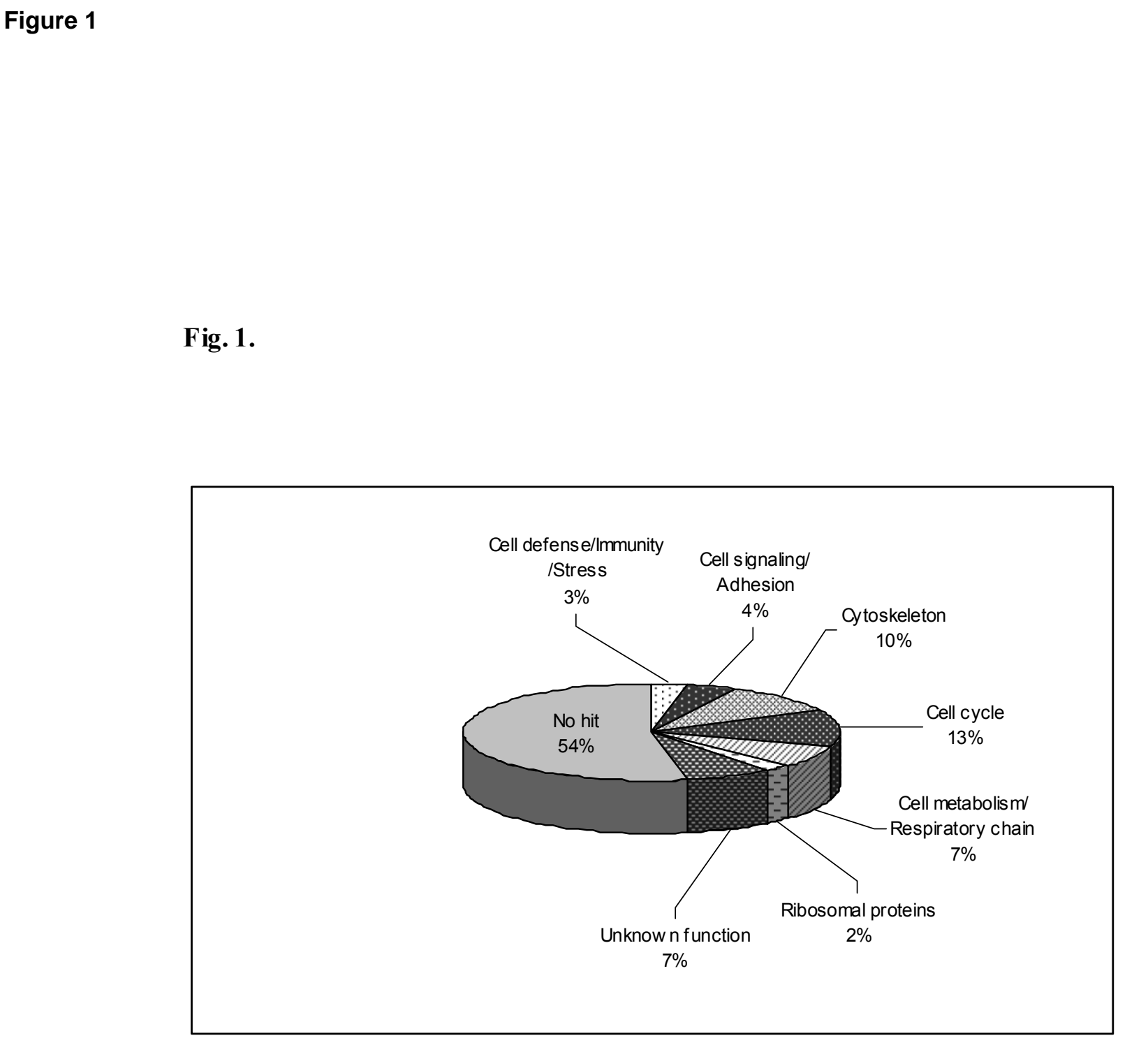

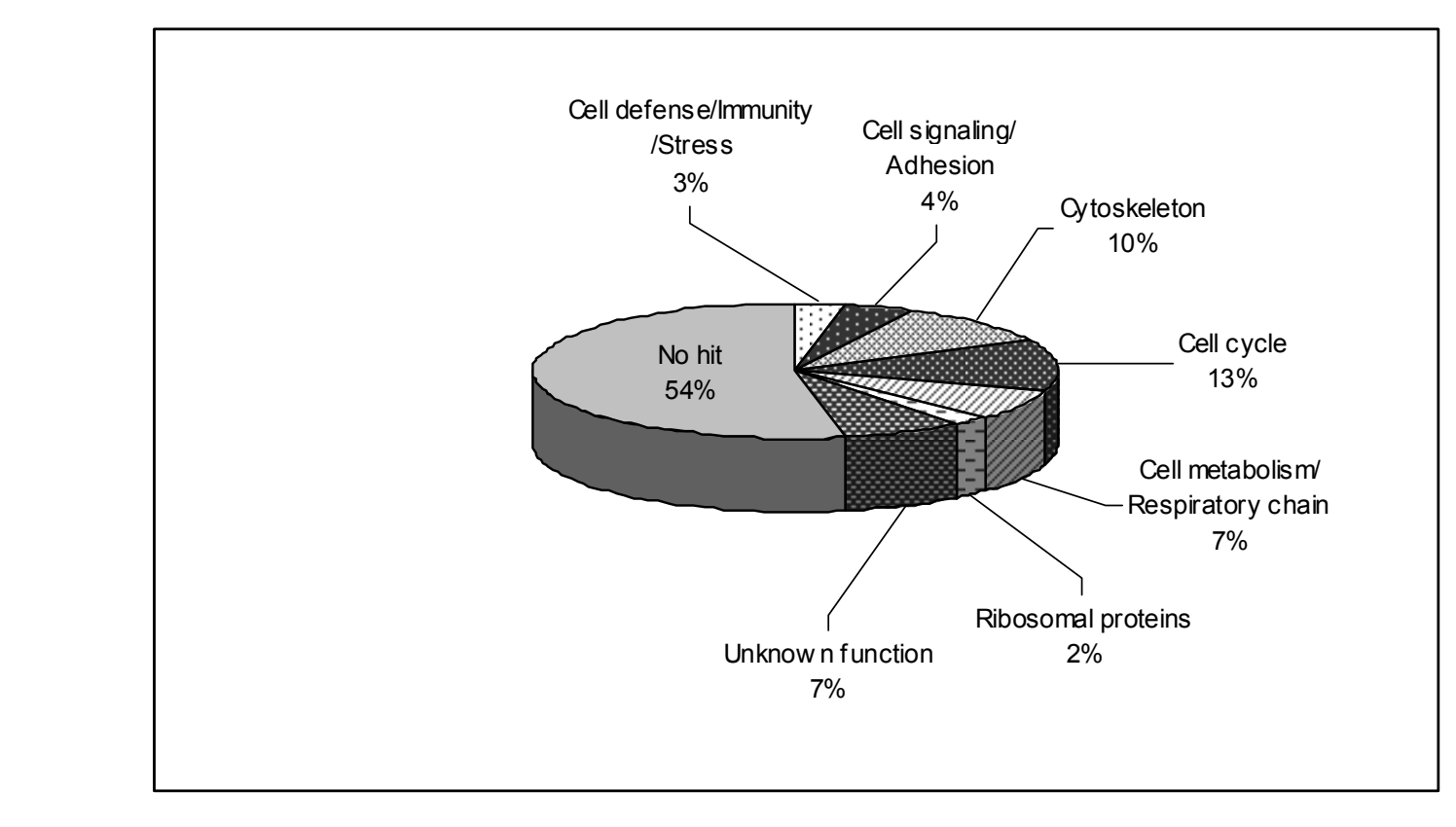

Figure 1 (Stress
Fig. 1.

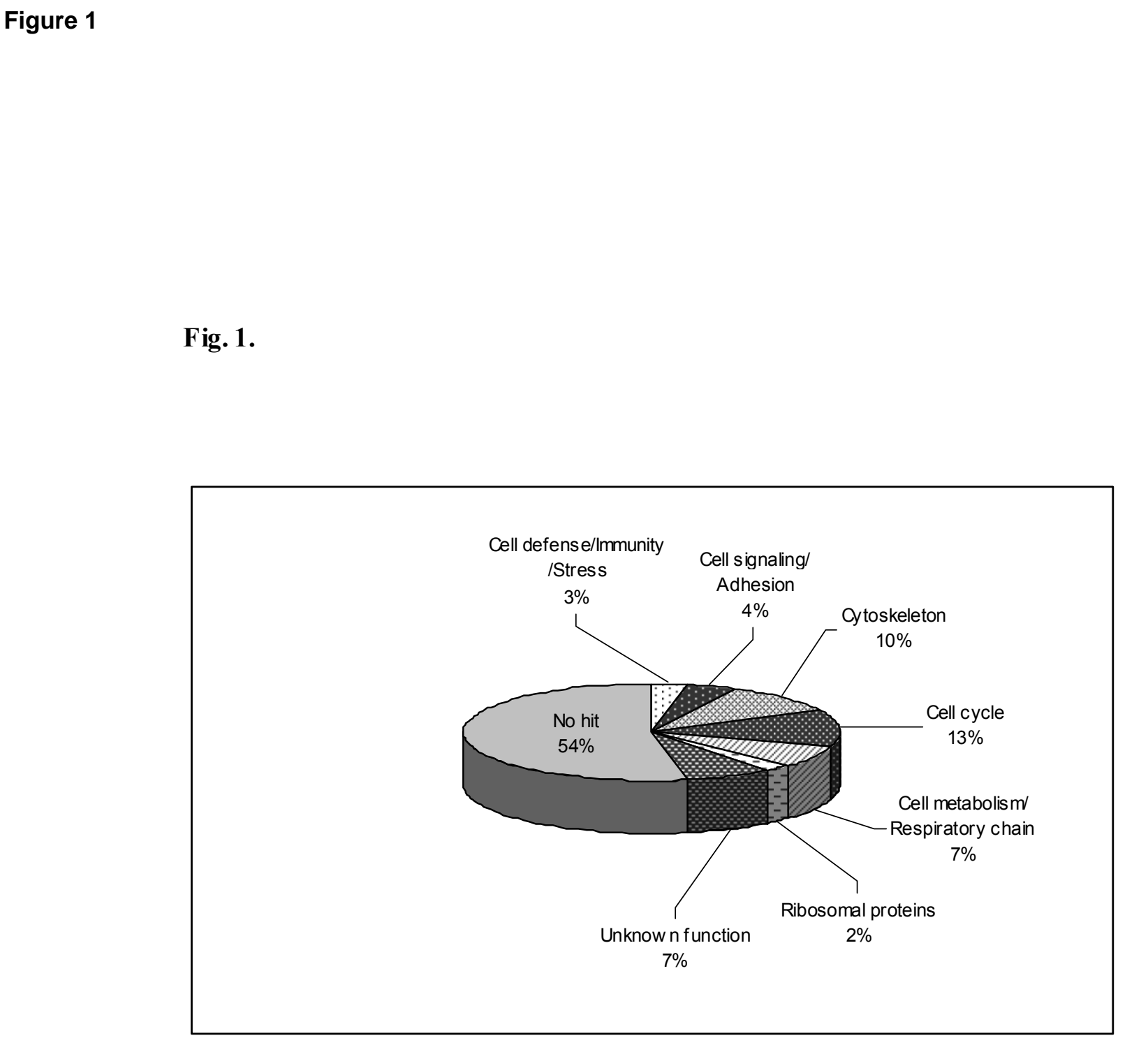

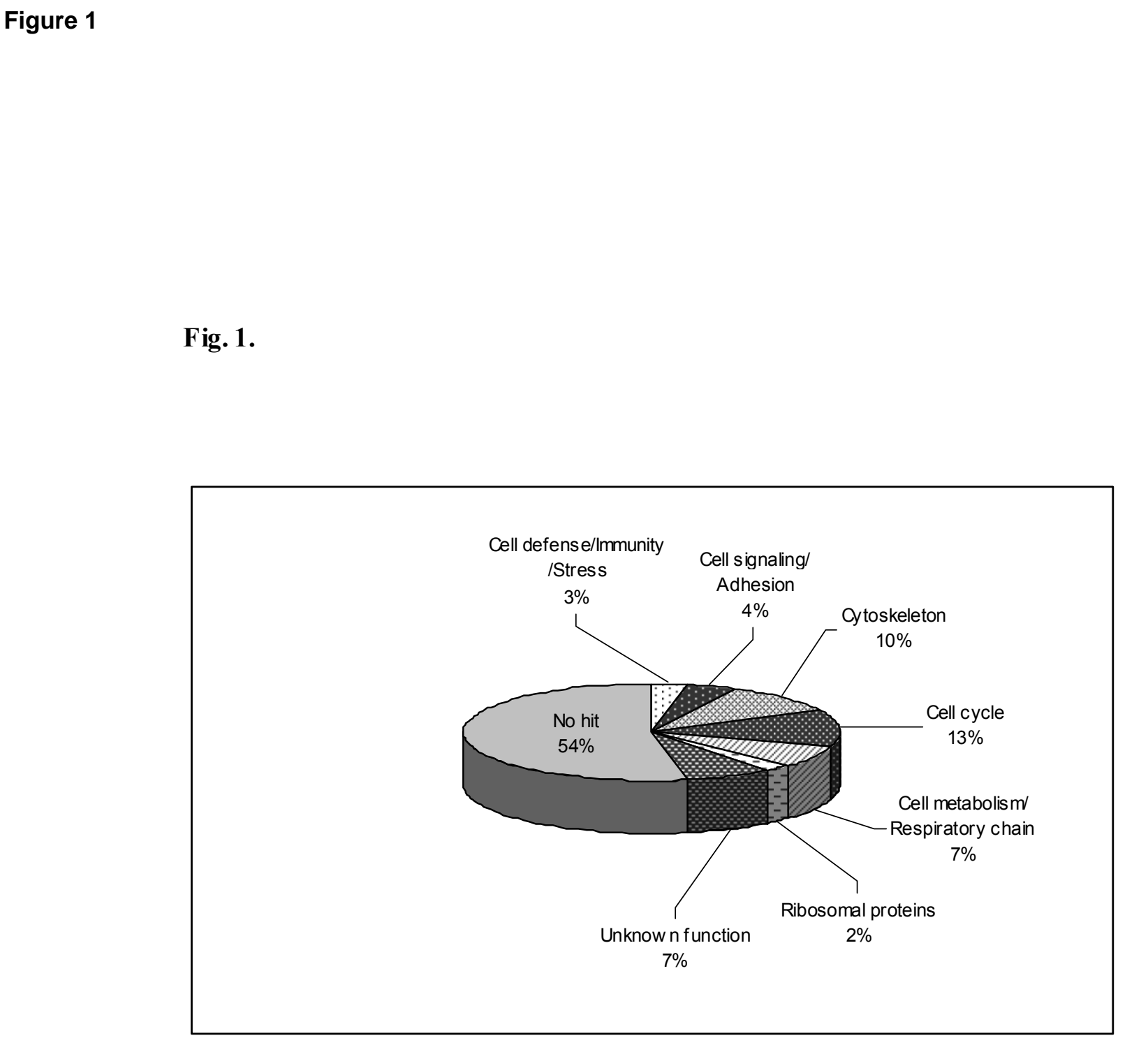

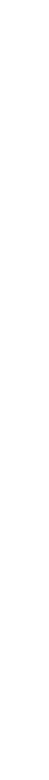


Fig 2.

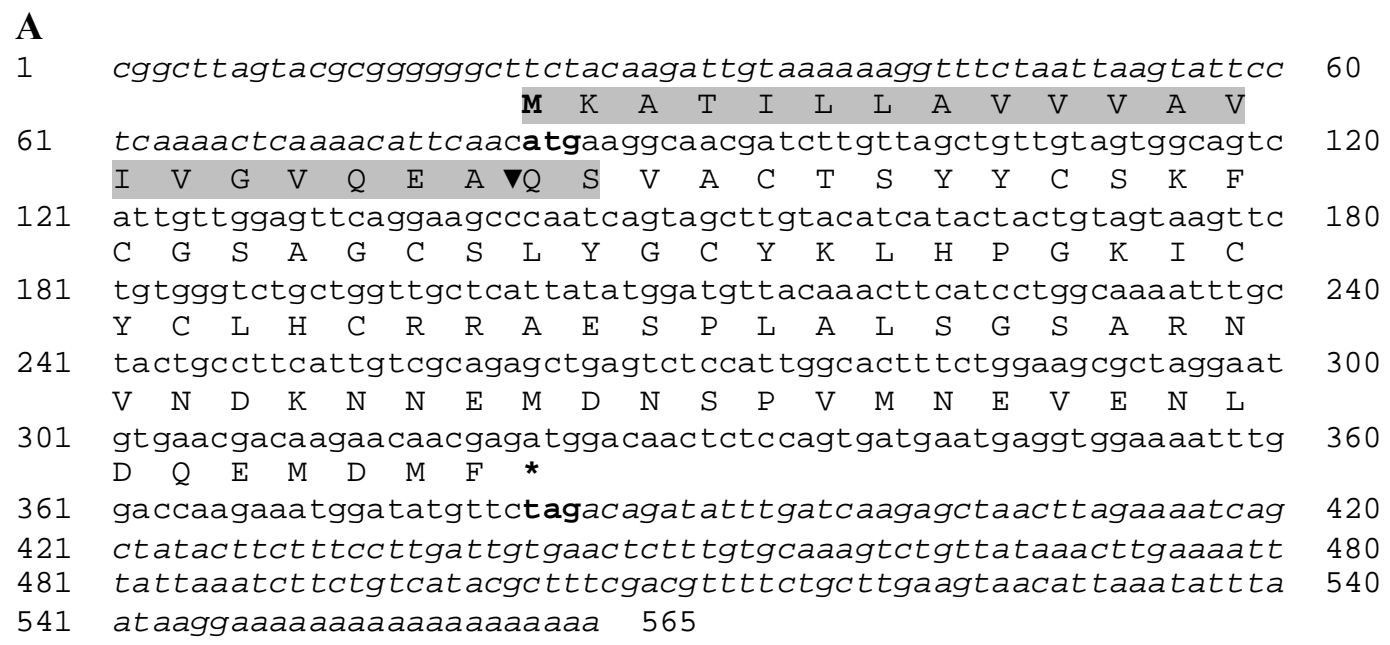

B

1 cggcttagtacgcggggggcttctacaagattgtaaaaaggtttctaattaagtattcc $\begin{array}{llllllllllllll}M & K & A & T & I & L & L & A & V & V & V & A & V\end{array}$

61 tcaaactcaaagcattcatcatgaaggcaacgatcttgttagctgttgtagtggcagtc $\begin{array}{llllllllllllllllllllllllllll}I & V & G & V & Q & E & V & Q & S & \nabla V & P & C & A & S & T & Y & C & A & R & F\end{array}$

121 attgttggagttcaagaagtccaatcagtaccttgtgcatcaacctactgtgctaggttc $\begin{array}{llllllllllllllllllllllllllll}C & G & S & A & G & C & L & K & Y & G & C & Y & R & L & H & P & G & K & I & C\end{array}$

181 tgtgggtctgctggttgcttaaatatggatgttacagacttcatcccggcaaatttgC $\begin{array}{lllllllllllllllllllll}Y & C & L & H & C & R & R & A & E & S & P & L & A & L & S & G & S & A & R & N\end{array}$

241 tactgccttcattgtagaagagctgagtctccattggcactttctggaagcgctaggaat $\begin{array}{llllllllllllllllllll}\mathrm{V} & \mathrm{N} & \mathrm{D} & \mathrm{K} & \mathrm{N} & \mathrm{N} & \mathrm{E} & \mathrm{M} & \mathrm{D} & \mathrm{N} & \mathrm{S} & \mathrm{P} & \mathrm{V} & \mathrm{M} & \mathrm{N} & \mathrm{E} & \mathrm{M} & \mathrm{E} & \mathrm{N} & \mathrm{L}\end{array}$

301 gtgaacgacaagaacaacgagatggacaactctccagtgatgaatgagatggaaatttg $\begin{array}{lllllllll}D & Q & E & M & D & M & F & \text { * }\end{array}$

361 gaccaagaaatggatatgttctagacagatatt gatcaagagctaacttcaaaatcag 421 ctatacttcttccttgatggtgaacactttgcgcaagtctgttataacttgacaatta 481 ttaatcttctgtcatacgcttcgacgtttctgcttgaagtaacattaatattaat 541 aaggaaaaaaaaaaaaaaa 563

C

$\begin{array}{llllllllllllllllll}M & \mathrm{~K} & \mathrm{~A} & \mathrm{~T} & \mathrm{I} & \mathrm{L} & \mathrm{L} & \mathrm{A} & \mathrm{V} & \mathrm{V} & \mathrm{V} & \mathrm{A} & \mathrm{V} & \mathrm{I} & \mathrm{V} & \mathrm{G} & \mathrm{V} & \mathrm{Q}\end{array}$ ttgaacatgaaggcaacgatcttgttagctgttgtagtggcagtcattgttggagttcag $\begin{array}{llllllllllllllllllll}E & V & Q & S & \nabla V & P & C & A & S & T & L & C & S & R & F & C & G & S & A & G\end{array}$

61 gaagtccaatcagtaccttgtgcatcaaccttgtgtagtaggttctgtgggtctgctggt $\begin{array}{lllllllllllllllllllllllllllllll}C & R & L & Y & G & C & Y & R & L & H & P & G & K & I & C & Y & C & L & H & C\end{array}$

121 tgcagattatatggatgttacagacttcatcccggcaaatttgctactgccttcattgt $\begin{array}{llllllllllllllllllll}R & R & A & E & S & P & L & A & L & S & G & S & A & R & N & V & N & D & Q & N\end{array}$

181 cgcagagctgagtctccattggcactttctggaagcgctaggaatgtgaacgatcagaac $\begin{array}{lllllllllllllllllllll}K & E & M & D & N & S & P & V & M & N & E & M & E & H & L & D & Q & E & M & D\end{array}$

241 aagagatggacaactctccagtgatgaatgagatggaacatttggaccaagaatggat M F *

301 atgttctagacagatatttgatcaagagctaacttagaaatcagctatacttcttcct 361 tgatggtgaacaatttgttcaaagtctgttataaacttgacaatttattaaatcttctgt 421 catacgcttcgacgttttctgataagccacattaaatatttaataaggaaaaaaaaa 60 
Figure 3

Fig 3.

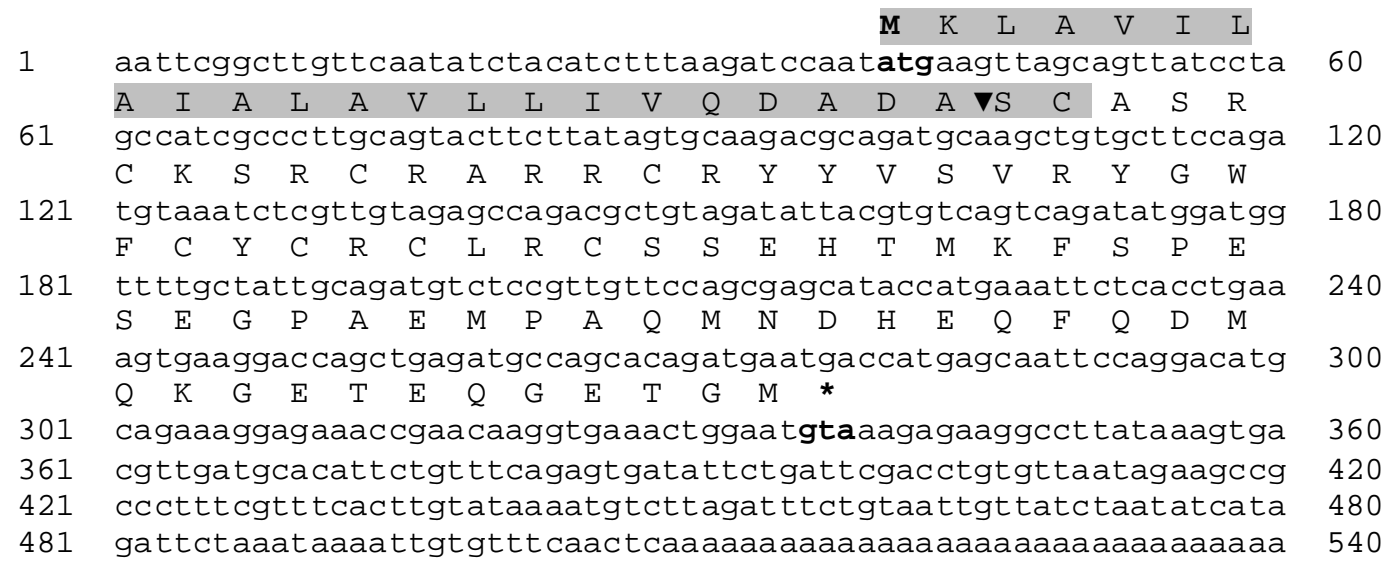


Fig. 4.

A

Clam Myticin form 3 $\mathrm{Clam}$ Myticin form 2 $\mathrm{Clam}$ Myticin form 1

Myticin B

Consensus cystein array
MKAT I LLAVVVA VI VGV QE VQS VPCAS TLCSRFCGSA GCRLY GCYRL HP GKI CYCLHCRRAE SP LAL SGSARNVNDQNKEMD NSPVMNEMEHLDQEMDMF MKAT I LL AVVVA VI VGV QE VQS VP CAS TY CARFC GSA GCLKY GCYRL HP GKI CYCLH CRRAE SP LAL SGSARNVNDKNNEMD NSPVMNEMENLDQEMDMF MKAT I LLAVVVA VI VGVQE AQS VACTS YY CSKFC GSA GC SLY GCYKL HP GKI CYCLH CRRAE SP LAL SGSARNVNDKNNEMD NSPVMNE VENLDQEMDMF MKAT I LLAVLVAVF VAGTE AHS HACTS YWCGKFC GTA SCT HY LCRVL HP GKMCACVH CSRVNNP FRVNOVAKS IN ----DID YTP IMKSMENLDNGMDM MKATMLLAVVVA VEVAGTE AHP HVCTS YY CSKFC GTA GCTRY GCRNL HRGKLCECLHCSRVKFPFGA TQDAKSMN----ELE YTP IMKSMENLDNGMDM

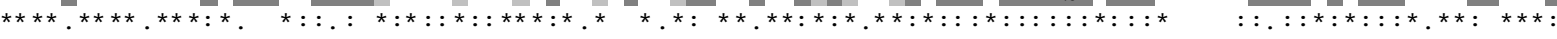

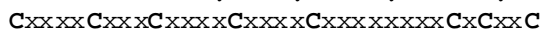

\section{B}

Mytilin_c

Clam Mytilin

Mytilin B

Mytilin $G 1$

Mytilin A

Mytilin

Consensus cystein array
MKLAVI LAI AL AVL LI VQD AD ASCAS RCK SRCRS RRCRY YVSVR YGWFC YCKCL RCSSE HTMKF SPESE GP --- -AEMP AQMND HEQFQDMQKGETEQGETGM MKLAVI LAI ALAVL LI VQD AD ASCAS RCK SRCRARR CRY YVSVR YGWFC YCRCL RCSSE HTMKF SPESE GP ----AEMP AQMND HEQFQDMQKGETEQGETGM MKAA VI LAI ALVAI LAVHE AE ASCAS RCK GH CRA RRCGY YVSVL YRGRC YCKCL RCS SE HSMKF P ENEG S SP SD MMP QMNENEN TEF GQDMP TGETEQGETGI CCASRTKAKCAGRRCKGWSASERGRCY CCASTRAKCARR

GCAS TCKAKCAGRRCKGWASAS FRRRCYCKCF RC

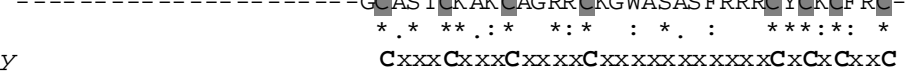




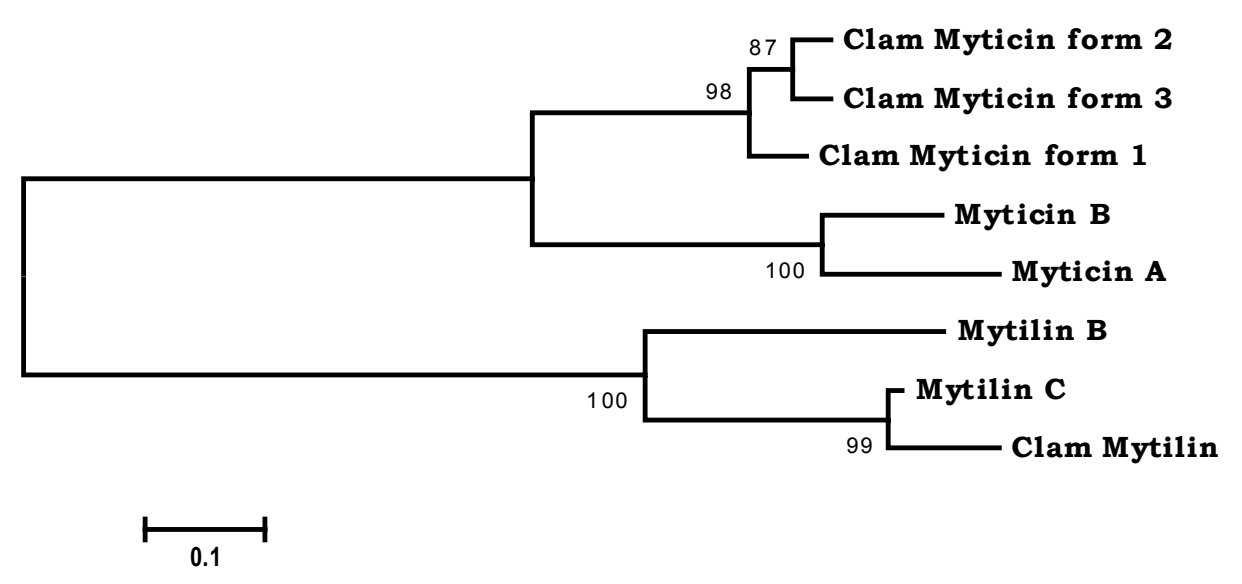

Figure 5

0.1

\section{Fig. 5.}


Fig. 6.

A.

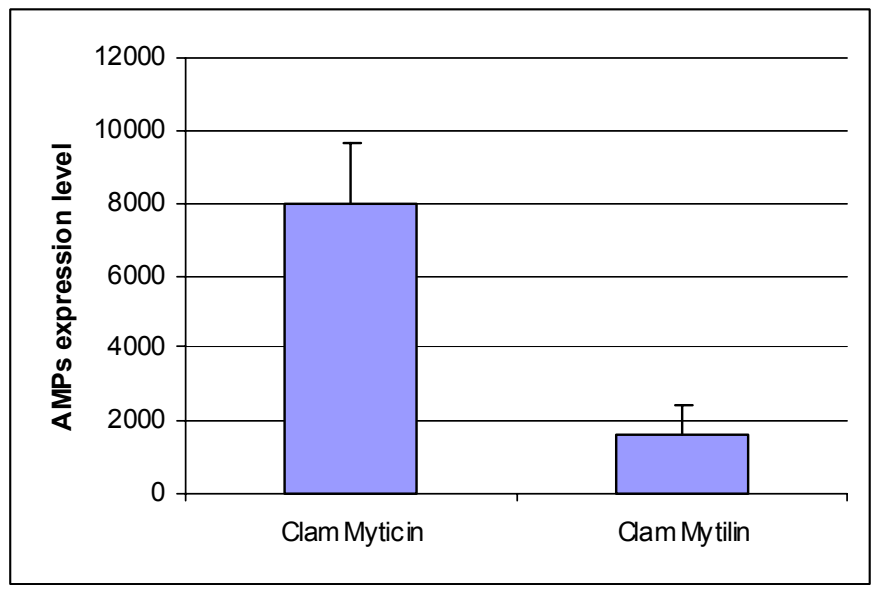

B.

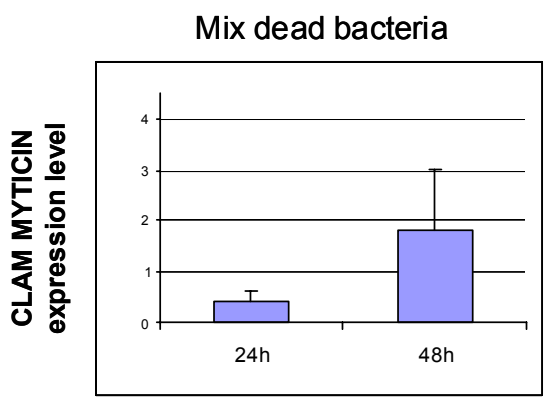

Vibrio anguillarum
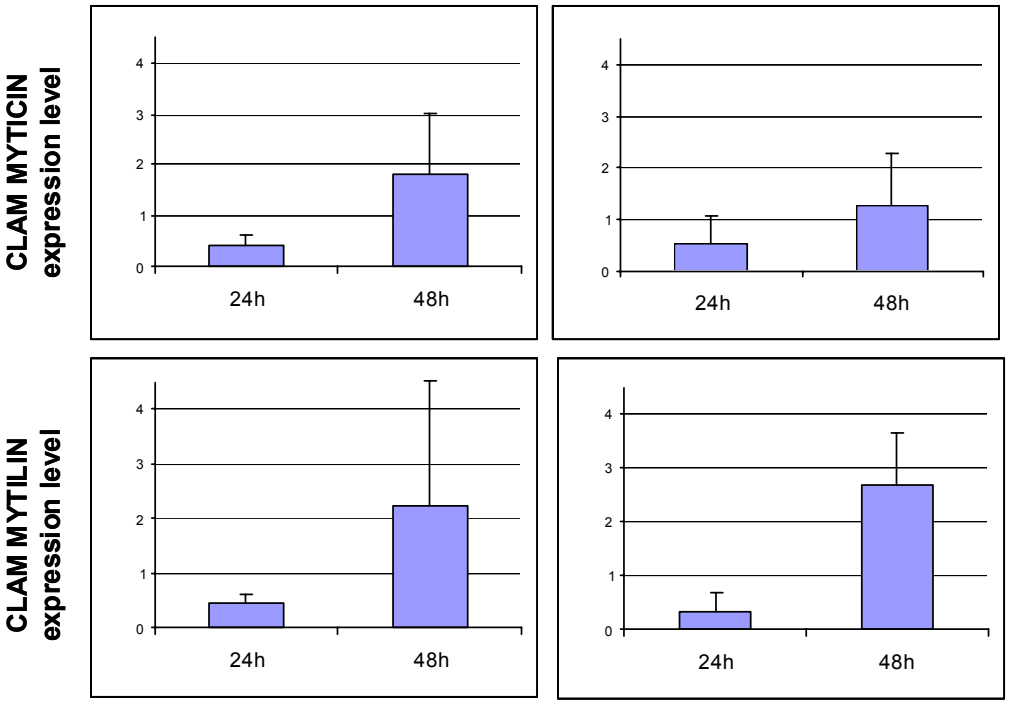


\author{
Dr. Tristan RENAULT \\ IFREMER \\ Laboratoire de Génétique, Aquaculture et Pathologie \\ B. P. 133 \\ 17390 La Tremblade \\ FRANCE
}

Tel : 0546369836

Fax : 0546363751

E-mail : trenault@ifremer.fr

\title{
Philippe Roch
}

Equipe Pathogènes et Immunité UMR CNRS Ecolag, cc 093 Université de Montpellier 2 Place Eugène Bataillon F-34095 MONTPELLIER cedex 5

tel: 33 (0)4671447 12 fax: 33 (0)4 67144673

e-mail: Philippe.Roch@univ-montp2.fr

http://www.ecolag.univ-montp2.fr

\author{
Paola Venier \\ Dept. Biology, University of Padova \\ Via Bassi 58/B \\ 35131 Padova, Italy \\ voice +39-049-8276284 \\ fax $+39-049-8276280$ \\ e-mail paola.venier@unipd.it \\ Gerardo R. Vasta, Ph.D. \\ Professor \\ Center of Marine Biotechnology \\ University of Maryland \\ Biotechnology Institute \\ Suite 236, Columbus Center \\ 701 East Pratt Street \\ Baltimore, MD 21202 \\ Phone: 410.234.8826 \\ Lab: 410.234.8827 \\ E-mail:vasta@umbi.umd.edu \\ Website: http://www.umbi.umd.edu/centers/comb.html
}


Table 1. Identified SSH up-regulated clones in dead bacterial challenged $R$. decussatus with significant database match.

\begin{tabular}{|l|c|c|c|c|}
\hline Category and ge ne identity. Blast-X & $\begin{array}{c}\text { Genbank } \\
\text { Accession nomolog species }\end{array}$ & $\begin{array}{c}\text { Insert } \\
\text { size (bp) }\end{array}$ & $\begin{array}{c}\text { e- } \\
\text { value }\end{array}$ & clones./n ${ }^{\mathbf{0}}$ contigs \\
\hline
\end{tabular}

\section{$\underline{\text { Cell defense/ immunity/ stress }}$}

Myticin-B precursor
Mytilin C precursor
Inhibitor of apoptosis protein 2
Heat shock cognate 70
Ferritin

Naegleriapore A pore-forming peptide prec ursor

$\begin{array}{llllc}\text { EL903763 } & 386 & \text { Mytilus galloprovincialis } & 4 \mathrm{e}-14 & 1 \\ \text { EL903793 } & 280 & \text { Mytilus trossulus } & 3 \mathrm{e}-21 & 1 \\ \text { EL903725 } & 308 & \text { Danio rerio } & 1 \mathrm{e}-12 & 1 \\ \text { EL903717 } & 761 & \text { M.galloprovincialis } & 1 \mathrm{e}-113 & 2 / 1 \\ \text { EL903718 } & 900 & \text { Crassostrea gigas } & 1 \mathrm{e}-20 & 2 / 1 \\ \text { EL903762 } & 610 & \text { Naegleria fowler } & 3 \mathrm{e}-11 & 1\end{array}$

\section{Cell signaling/ Adhesion}

CDH1-D (E- Cadherin)

G-Cadherin

EFHC2 (EF-hand domain. Calcium ion binding)

Signal sequence receptor beta-like protein

Proline-rich transmembrane protein 1

CG14991-PA, isoform A

Longin-like

\section{Cytoskeleton}

Actin

Actin-binding/filamin-like prote in

ENSANGP00000003616 (filamin family)

Ppp2r1 a-provprotein

Actophorin

Collagen, type VIII

High-glyc ine tyrosine keratin type II.4

Inter-alph a-trypsin inhibitor heavy chain $\mathrm{H} 3$

$\mathrm{P}$ aramyosin protein

Radixin

CG33253-PA

TYB12_ONCMY Thymosin beta-12

\section{Cell cycle}

Deoxyhypusine synthase

Mantle gene 6

Heavy metal-binding protein HIP

Metal-dependent RNase

Polyubiquitin

Ubiquitin A-52 residue ribosomal prote in fusion product 1

$60 \mathrm{kD} \mathrm{Ro} / \mathrm{SSA}$ autoantigen isoform 2 or Sjogren
EL903726 720

EL903749 514

EL903729 337

EL903767

EL903760

EL903779

EL903778

EL903720

EL903721

EL903722

EL903719

EL903761

EL903748

EL903747

EL903784

EL903783

EL903781

EL903739

EL903738

EL903768

EL903750

462

384

585

235

564

418

616

220

649

653

563

721

458

460

EL903737

EL903751

EL903752

EL903753

EL903785

EL903770

EL903769

EL903780

EL903728

445

451

682

474

305

274

212

175

772
Gallus gallus

Strongylocen trotus purpuratus

S.purpuratus

C. gigas

Homo sapiens

Tribolium castaneum

Medicago truncatula

Mus musculus

Schistosoma mansoni

Anopheles gambiae

Xenopus laevis

Entamoeba histolytica

G. gallus

M. musculus

H. sapiens

C. gigas

M. musculus

T. castaneum

Oncorhynchus mykiss

M. musculus

Pinctada fucata
M. edulis

Lactococcus lactis

S. purpuratus

S. purpuratus

Pan troglodytes 2e-37

$4 / 1$

$7 \mathrm{e}-5$

$1 \mathrm{e}-49$

2e -44

$5 \mathrm{e}-7$

$3 e-45$

$3 e-8$

$3 e-75$

$5 / 3$

$5 e-23$

$3 / 1$

$2 \mathrm{e}-33$

$2 \mathrm{e}-63$

$1 \mathrm{e}-15$

$3 e-5$

2e-19

$3 \mathrm{e}-44$

$6 e-22$

1e-100

$1 \mathrm{e}-15$

2e-12

$2 e-67$

$2 e-6$

$8 / 3$

$3 e-3$

$1 e-4$

5e-32

$3 e-20$

$2 e-33$

(1)

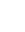


syndrome antigen $\mathrm{A} 2$.

Elongation factor-1 alpha

$\begin{array}{lcllc}\text { EL903744 } & 343 & \text { Calyptogena soyoae } & 3 \mathrm{e}-57 & 9 / 1 \\ \text { EL903745 } & 567 & \text { Atypus snetsingeri } & 6 \mathrm{e}-37 & 1 \\ \text { EL903746 } & 393 & \text { Nereis virens } & 8 \mathrm{e}-55 & 1 \\ \text { EL903758 } & 134 & \text { X. tropicalis } & 2 \mathrm{e}-5 & 2 / 1 \\ \text { EL903740 } & 310 & \text { P. troglodytes } & 8 \mathrm{e}-4 & 1 \\ \text { EL903764 } & 96 & \text { Aedes aegypti } & 1 \mathrm{e}-6 & 2 / 1 \\ \text { EL903759 } & 452 & \text { D. rerio } & 6 \mathrm{e}-25 & 1 \\ \text { EL903777 } & 385 & \text { T. castaneum } & 1 \mathrm{e}-17 & 1\end{array}$

\section{Cell Metabolism/ Re spiratory chain}

Cytoc hrome oxidase subunit I

Cytochrome c subunit II

Hypothetical proteinXP_780193

Proliferated association protein 1 isoform

MGC80785 prote in

Sarcoplasmic calcium binding protein

Acetyl-coenzyme A acyltransferase 2

GTP-binding protein

Similar to plac ental protein 11

Carbonic anhydrase

\section{Rab GTPase}

Receptor of Activated Kinase C 1

Purine-rich binding protein-alpha

Hypothetical protein TTHERM_02141640

\begin{tabular}{|c|c|c|}
\hline EL903756 & 460 & Ruditapes decussates \\
\hline EL903741 & 295 & Ruditapes philipp inarum \\
\hline EL903788 & 637 & S. purpuratus \\
\hline EL903731 & 697 & S. purpuratus \\
\hline EL903757 & 322 & X. laevis \\
\hline EL903754 & 557 & Pseudocardium sybillae \\
\hline EL903743 & 374 & X. laevis \\
\hline EL903782 & 698 & P. fucata \\
\hline EL903716 & 702 & S. purpuratus \\
\hline EL903732 & 735 & Anthopleura elegan tísima \\
\hline EL903742 & 358 & Dictyostelium discoideum \\
\hline EL903730 & 307 & Mya arenaria \\
\hline EL903791 & 382 & S. purpuratus \\
\hline EL903735 & 450 & Tetrahymena thermophila \\
\hline
\end{tabular}

$\begin{array}{lc}3 e-76 & 1 \\ 7 e-27 & 1 \\ 9 e-3 & 1 \\ 4 e-88 & 1 \\ 3 e-24 & 1 \\ 2 e-4 & 3 / 1 \\ 2 e-36 & 1 \\ 2 e-135 & 1 \\ 5 e-37 & 2 / 1 \\ 1 e-26 & 1 \\ 4 e-15 & 2 / 1 \\ 5 e-44 & 1 \\ 3 e-8 & 1 \\ 1 E-22 & 1\end{array}$

\section{$\underline{\text { Ribosomal proteins }}$}

Ribosomal protein L13

Ribosomal protein L28

Ribosomal protein P2-like

Ribosomal protein L19

40S ribo so mal protein $\mathrm{Sa}$

Ribosomal protein $\mathrm{L} 7$

$\begin{array}{ll}\text { EL903773 } & 306 \\ \text { EL903775 } & 209 \\ \text { EL903774 } & 400 \\ \text { EL903771 } & 240 \\ \text { EL903727 } & 22 \\ \text { EL903772 } & 24\end{array}$

D. rerio
Haliotis asinina
Culicoides sonorensis
C. gigas
Ictalurus punctatus
C. gigas

$6 e-23$

$3 e-12$

$3 e-18$

$3 e-34$

$5 e-33$

3 e- 15

EL903733

758

EL903723

765

EL903724

393

EL903734

343

Z29075 myophilin antigen

EL903736

350

GM2 activator protein (ganglioside M2)

EL903765

376

Conserved hypothetical protein

EL903787

EL903755

373

CG7997-PA

EL903776

345

CG3612-PA isoform 2

EL903789

438

GA14397-PA.

Hypo thetical protein LOC556586

LSM14 homolog B

EL903790

367

545

Plasmodium falcipa rum

$1 \mathrm{e}-3$

$8 \mathrm{e}-33$

$1 \mathrm{e}-9$

$9 \mathrm{e}-13$

1e-8

2e-16 3/1

$1 \mathrm{e}-18 \quad 2 / 1$

$9 \mathrm{e}-40$

$4 \mathrm{e}-75$

$4 \mathrm{e}-8$

EL903792

$5 e-14$

$1 \mathrm{e}-7$

1

1

1


Hypo thetical protein

Hypothetical protein M04C7.2
EL903766

EL903786
316

382
Rattus norvegicus

Caenorhabditis elegans
$5 e-8$

$3 e-3$
1 
Table 2. General characteristic of ESTS obtained from hemocytes of $R$. decussatus challenged with a mixture of dead bacteria.

\begin{tabular}{lc}
\hline Category & Total ESTs \\
\hline \hline Total number of EST sequenced & 283 \\
Total number of EST analyzed & 253 \\
Significant matches to known proteins & 119 \\
EST clusters & 78 \\
Singletons & 44 \\
No significant match to database & 134 \\
Redundancy & $63 \%$ \\
\hline
\end{tabular}

